\title{
The beach degradation and sustainable management of the sandy coast: the Yilan coast of Northeastern Taiwan
}

\author{
H. M. Lin, F. M. Chu \& Y. T. Huang \\ Department of Geography, National Taiwan Normal University, Taiwan
}

\begin{abstract}
The purpose of this research is to improve the knowledge of citizens towards the Yilan coastal area. The basic ideas behind this project are to reduce the degree of usage of limited natural resources and to preserve the coastal area. First, it is important to devise the evaluation of the degradation status for the region. The study area is Yilan's sandy coast. The beach is the frontline among all the physical features regarding its function to the inner land protection. Thus, this research is to establish the indicator system to evaluate beach degradation which includes beach erosion, deforestation, seawater intrusion, shoreline retreat and increase of artificial structures on the beaches with the application of digital elevation models to simulate the study areas and to calculate the volumetric change between seasons and years. Therefore, monthly documentation on the beach litter has discovered several interesting indicators to support the evaluation of beach degradation. The results of beach budget and littering records can be analyzed to figure and explain the phenomena and cause of beach degradation, thus to solve the issues. At the end, based on the evaluation results and degradation level, a preservation strategy to manage the sustainable coastal zone will be proposed.
\end{abstract}

Keywords: beach morphology, coastal management, beach degradation, shoreline change, GIS.

\section{Introduction}

The coast is the frontline of homeland security against Mother Nature. It can be divided into several physical units such as the beach, sand dunes, wetland, and villages. Among these sectors, the sandy beach is the most vital one because it 
serves as the buffer zone before the waves hit the sand dunes. In addition, the sandy beach is also a tourist hot spot, a perfect laboratory and an excellent habitat for creatures. However, most of the sandy beach in Taiwan is wave sensitive; its sediment can drift away by the change of processes, thus, to lead to the retreatment of the shoreline. Another significant fact is that with the rapid development of urbanization and urban sprawl, the coastal zone has become one of the most popular areas for the real estate industry. Rapid population growth in the past decades has resulted in many environmental crises such as seawater contamination, beach pollution and land subsidence. The purpose of this research is to devise an indicator system to evaluate the degradation intensity and its causes for the preparation of a sustainable management plan for the Yilan coast.

\section{Study area}

Located in the Northeastern corner of Taiwan where the county meets the sea. Yilan coast is surrounded by the Central Mountain Range and faces the Pacific Ocean. Yilan's sandy coast encompasses 30 kilometres of county coastline and numerous Pacific beaches. A natural sand dune extends from north to south along the coastline. The estuary formed by the Lanyang River in the center of Yilan County creates the unique geographical entities and also influences the morphological characteristics of the beaches. The sand spits on both sides of Lanyang River are considered one of the most important wetlands in Taiwan. The Island of Gueishan is 10 kilometers away from the Yilan coast. Most of the population on the Island was relocated due to the Taiwanese military manoeuvres in the early 50s [1].

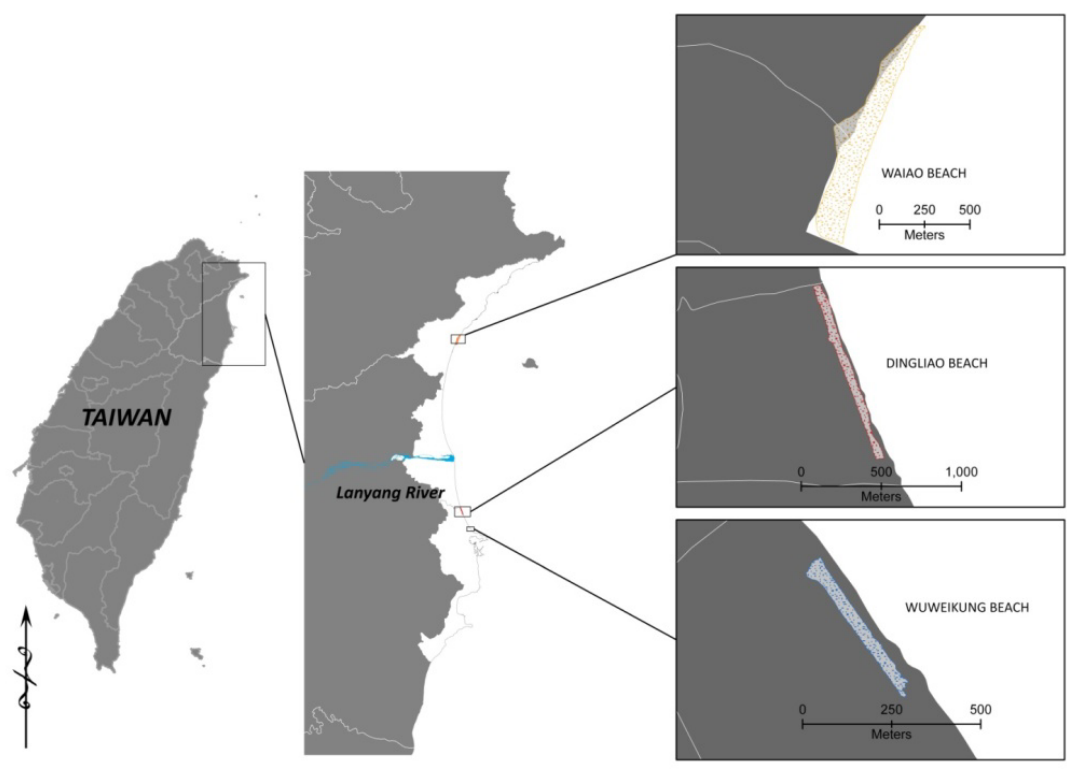

Figure 1: $\quad$ Yilan coast and the 3 operating areas. 
The stretch of sandy beach in Yilan could be identified into several individual beaches. These beaches have similar physical features but the socio-status differentiate each other. Theoretically, within the proposal area, the sand flux along the alongshore current from north to south in the summer, but south to north in the winter. This implies that the sand volume on these sensitive beaches is unevenly distributed and sometimes, even with short-term incidents, such as typhoons, can severely erode the beach.

In the past decades, the landscape of Yilan coast has undergone a tremendous change. These changes include beach erosion, deforestation, seawater intrusion, shoreline retreat and an increase of artificial structures on beaches. Three study areas are Waiao Beach, Dingliao Beach and Wuweigang Beach as fig. 1.

\section{Methodology}

The term beach degradation comes from land degradation; it shares a similar concept which was first implemented in a dry zone. It is usually defined as the decrease of vegetation and the characteristic change of soil. In a study, Kiunsi and Meadows [2] used the degradation evaluation on vegetation and soil to estimate the land degradation level of Tanzania. Al-Awadhi et al. [3] listed the degradation indicators for Kuwait including soil erosion, decrease of vegetation and soil contamination and assigned the three degradation levels.

In a study of beach degradation, $\mathrm{Cu}$ [4] discovers the beach erosion nearby the Niger River delta and claimed that the human intervention is one significant element on beach degradation. James [5] points out many of the Australian beaches face serious environmental problems such as storage for beach litter, urbanization, beach exploitation and beach erosion. Luci et al. [6] also indicate engineering projects can result in significant effect over the beach erosion.

\subsection{Acquirement of indicator}

Many studies over the recreational beaches have established the beach quality evaluation. Leatherman [7] listed 50 matters to evaluate 650 beaches in the States, and these evaluation standards include beach physical features and human utilization. Luci et al. first inserts beach user perception in the evaluation of beach. Roca et al. [8] combines the beach utilization and beach user perception to evaluate the Spanish beach quality.

This research defines the beach degradation by loss or recession of its functions. This research will evaluate the beach degradation intensity based on three conditions such as beach erosion, beach litter, artificial structures effect and beach user perception.

\subsection{Application of digital elevation model}

The most common digital data of the Earth's surface is the cell-based digital terrain model because of its ease of computer implementation and computational efficiency. The digital terrain model represents continuous surfaces of the ground by a large number of selected points with known X.Y.Z coordinates. Based on 
these coordinates, sets of high-accuracy digital terrain models can be structured and also to modelize morphological phenomena in different subjects. There are many studies about the coastal erosion and shoreline movements; however, most of these studies focus on the adjustment of waterline or change of the beach area. To fully investigate the coastal movement, volumetric analysis not only detects the size of the beach but can be integrated with other sources of data such as height of tide and wave.

To make up for the limitation of chronic presentation, some incidents occurring seasonally within a year could be considered significant as well, for instance, tropical storms, also known as typhoons. These incidents usually summon disasters at the coastal area cause losses of life and property loss. Other than that, storms can sometimes stimulate the process of beach degradation or sand volume loss. Indeed, field observation and on-site surveying could result from information in the minimum scale to compensate the lack of beach state record. Surveying brings valuable first-hand data back in the laboratory. Most of this raw data needs to be processed into applicable attributes.

\subsection{Beach morphodynamics}

The beach morphodynamics is mainly focused in years of the long-term (19782006), mid-long-term (1992-2000, 2005-2006), and short-term (early spring, before and after typhoon season, and late winter in year of 2009).

Collection of topography maps from Aerial Survey Office, elevation data for the Yilan coast from The First River Management Office, and field data survey are acquired and have been digitized into shoreline, profiles, and DEMs. Analysis based on these data has been carried out and generated reports in three temporal scales respectively. The budget analysis is performed between intertidal line and foredune.

\subsection{Accretion and erosion}

Between May, 1992 and June, 1994, the nearshore consists of a stable environment. Most of the beaches along Yilan coast have minor erosion in the winter and accretion in the summer. The Wushih harbour built in the late $80 \mathrm{~s}$ has started showing the impact on the shoreline change in northern Yilan coast.

Between October 1994 and June 1997, two beaches within the township of Suao started showing distinct shoreline accretion, and rest showed erosion. Since 1997, this accretion shoreline switched its direction and turned toward erosion such as the village of Wuweigang. Since then, the major beach morphological trend in Yilan coast is erosion, except the areas nearby the spits of Lanyang River.

From 1997 to 2000, there are eight typhoon surges; all the sandy beaches in Yilan coast are in erosion except the southern spit of the Lanyang River. Distinct loss of sandy beaches on the south side of the seawall of Wushih harbour can be shown in the end of 2000 . 


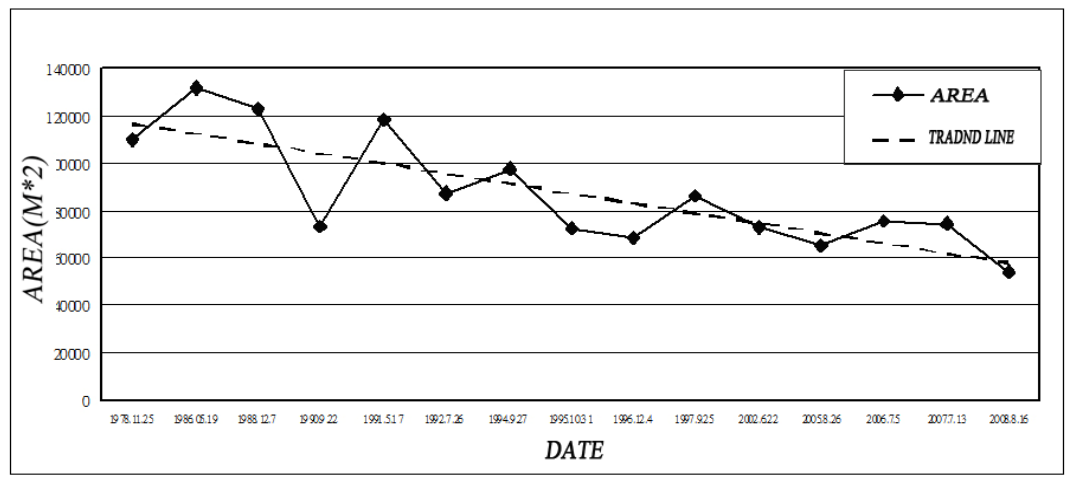

Figure 2: $\quad$ Beach area of Dingliao from 1978 to 2008.

\subsection{Volumetric change}

Between 2005 and 2006, the morphodynamics rate of Waiao Beach is $0.66 \mathrm{~m} / \mathrm{m}^{3}, 0.9$ for Dingliao Beach $\left(\mathrm{m} / \mathrm{m}^{3}\right)$, and 1.20 for Wuweigang Beach $\left(\mathrm{m} / \mathrm{m}^{3}\right)$.

The erosion intensity between 2005 and 2006 is Wuweigang (-63\%) > Dingliao (-39\%) > Waiao (-30\%). From February, 2009 to June, 2010, six field surveys have been conducted as shown in table 1 .

Table 1: $\quad$ Volumetric change from February 2009 to June 2010.

\begin{tabular}{|c|c|c|c|c|c|c|}
\hline & \multicolumn{2}{|c|}{ Waiao } & \multicolumn{2}{c|}{ Dingliao } & \multicolumn{2}{c|}{ Wuweigang } \\
\hline & volume $\left(\mathrm{m}^{3}\right)$ & change & volume $\left(\mathrm{m}^{3}\right)$ & change & volume $\left(\mathrm{m}^{3}\right)$ & change \\
\hline Feb. 2009 & 288,256 & & 34,265 & & 25,485 & \\
\hline May 2009 & $+274,902$ & $+95 \%$ & $+44,434$ & $+130 \%$ & $+18,300$ & $+72 \%$ \\
\hline Aug. 2009 & $+25,409$ & $+5 \%$ & -200 & $0 \%$ & $+1,428$ & $+3 \%$ \\
\hline Dec. 2009 & $-344,078$ & $-58 \%$ & $-45,526$ & $-58 \%$ & $-22,061$ & $-49 \%$ \\
\hline Feb. 2010 & $+28,407$ & $+12 \%$ & $-3,111$ & $-9 \%$ & $-1,324$ & $-6 \%$ \\
\hline Jun. 2010 & $+5,709$ & $+2 \%$ & $+3,263$ & $+11 \%$ & $+1,593$ & $+7 \%$ \\
\hline
\end{tabular}

\subsection{Beach structures}

There are various artificial structures within the study area. The most influential project is the Wushih Harbour. Wushih harbour was built in 1991 and the seawall extended in 2001. The local government plans to build cycling trails behind the sand dune.

The first river management office has installed a jetty system in the serious eroding beaches. With the evidence from three temporal scales, it shows that 
Dingliao beach has been eroding not only in the volumes but also elevation and areas.

In 2002, the first river management office has installed 21 armour units on the face of Dingliao and Wuweigang. As in fig. 3, the beach profile before the installation of armour units does not show a significant change when compare to after installation. However, in 2006 the profile shows the sand started accumulating in the spots where the armour units were installed. So it comes with a conclusion that the sand tends to accumulate nearby the armour units, the purpose of holding sand on the beach serves well.

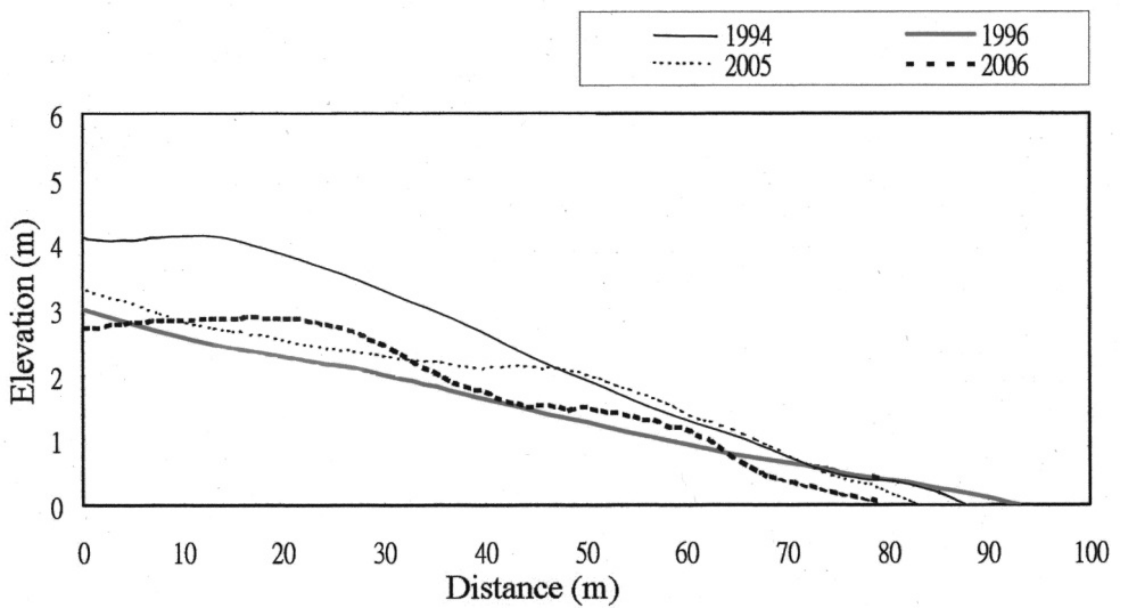

Figure 3: $\quad$ Beach profile before and after the installation of armour units.

\section{Beach litter}

Storrier et al. [9] documents the beach litter status monthly, and the surveying area is chosen randomly 100 meters from the max tidal line. Storrier also categorizes the litter based on 12 different materials. Madzena and Lasiak [10] survey three beach litters in South Africa monthly, and randomly pick the area of 3 meters wide.

In this research, a monthly beach litter survey is carried out and categorizes the litter based on its materials and amounts. From April, 2009 to July, 2009, four beach litter surveys have been conducted in three operating areas. The reports show that the beach litter in Dingliao is much higher than average.

\subsection{Amount change}

In April, the amount of beach litter decreases significantly after the beach cleanup. However, only one month after its cleanup the litter amount increased from 226 to 882 in May. Then, on the following surveys, the litter amount maintains from 872 to 882 . In July, the litter amount declined after locals clean 
up the beach. At the end, the beach litter amount in Dingliao decreases after the beach cleanup and before the typhoon arrives (fig. 4).

In Oct. 2009, typhoon Bama brought the largest precipitation in history to Yilan. Most of the coast and half of the county was flooded. A tremendous amount of garbage from inland was flushed into the sea and then drifted onto the Yilan Coast. In the first photograph the beach litter decreased distinctly after the cleanup, however, after the flood the second shows a "litter belt" that mostly contained driftwood.
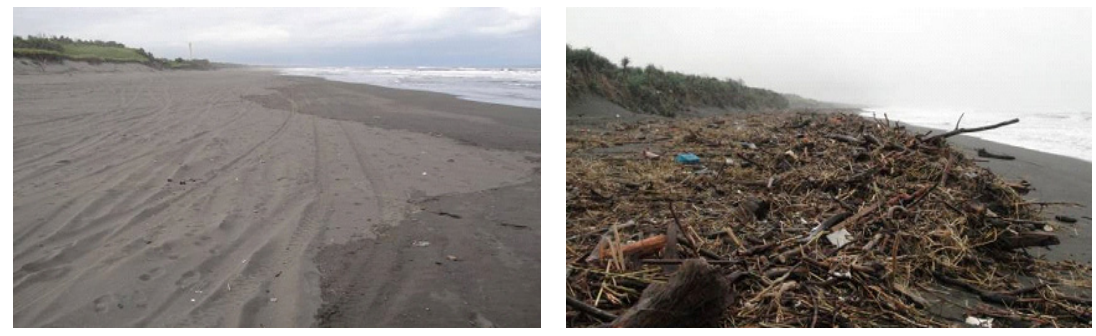

Figure 4: Beach litter before the beach cleanup (left) and after the typhoon Bama (right) in Dingliao Beach.

\section{User perception}

Beach user perception is included when evaluating beach environmental quality $[6,8,11]$. Tourists and locals are being interviewed on questions such as the reasons for coming to this beach, and if the beach litter has an important impact on the beach quality. Most of the locals also claim that the beach has been eroded and the shoreline has a retreating condition. User perception can also fill up the scarcity of qualitative studies.

The beach degradation evaluation is assigned in two categories, objective and subjective. Degradation indicators include beach erosion, artificial structures, and the change of beach litter for the objective evaluation, relatively; beach user perception is included in the subjective evaluation.

The results include a) Yilan coast is in an erosion condition in all temporal scales. b) Artificial structures in most cases increase the coastal erosion rate. c) Beach litter increases in winter and decreases the beach utilization. d) According to the user perception, beach litter has a negative influence on beach quality.

\section{Conclusion}

The environmental issues such as beach erosion and beach litter in Dingliao have to be solved in order to restore the beach functions. Beach erosion in different sectors of Yilan coast is influenced by a physical process, yet there can be evidence of human intervention in an attempt to slow down the erosion rate.

The installation of a jetty system may cause the cut and fill effect due to the beach compartment flow in Yilan coast. To increase the sediment supplement 
from Lanyang River by banning the sediment storage dam in upstream and midstream may be beneficial for stopping the beach erosion.

Furthermore, most of the beach litter comes from fishermen and beach tourists. Most of these beach users hold back when being asked if beach litter may be brought by fishermen, eel fry aquaculture workers and tourists.

To solve the issues above, propaganda on nearby fisheries and beach users is necessary. Moreover, public facility has to be improved to reduce the beach littering by tourists.

Lastly, the artificial structures that affect the beach morphology should be monitored consistently in case they increase the erosion rather than holding sand.

\section{Acknowledgements}

Thanks for the field survey team from the Geomorphology Lab at National Taiwan Normal University. Data appeared in this research was released by Taiwan's First River Management Office. This research is funded by the National Science Council, Taiwan. NSC grants: NSC97-2621-M-003-002, NSC98-2621-M-003-003, and NSC99-2621-M-003-005.

\section{References}

[1] Chu, F.M. and Lin, H.M. (2009): Proposal for the Investigation of Sandy Beach Erosion - A Case Study in Yilan, Taiwan: International Sediment Trap Workshop and International Symposium on Sediment Transport and Sedimentation on Asian Continental Margins 2009 (International Sediment Trap Workshop) and (International Symposium on Sediment Transport and Sedimentation on Asian Continental Margins) 2009/3/24 (NSC 97-2621-M003-002).

[2] Kiunsi, R. B. and Meadows, M. E. (2006): Assessing land degradation in the Monduli district, northern Tanzania, land degradation \& development, 17:509-525.

[3] Al-Awadhi J. M., Omar S. A. and Misak R. F. (2005): Land degradation indicators in Kuwait, 16:163-176.

[4] Cu, O. (1993): Land degradation and the coastal environment of Nigeria, Catena, 20(3): 215-225.

[5] James, R.J. (2000): From beaches to beach environments: linking the ecology, human-use and management of beaches in Australia, Ocean \& Coastal Management, 43:495-514.

[6] Luci, C. C. P., Jose, A. J., Carmen, M. and Rauqurio, M. da C. (2003): The influence of the environmental status of Casa Caida and Rio Doce beaches (NE-Brazil) on beaches users, Ocean \& Coastal Management, 46:10111030.

[7] Leatherman, S. P. (1997): Beach rating: a methodological approach, Journal of Coastal Research, 13(1):253-258.

[8] Roca, E., Riera, C., Villares, M., Fragell, R., and Junyent, R. (2008): A combined assessment of beach occupancy and public perceptions of beach 
quality: a case study in the Costa Brava, Spain, Ocean \& Coastal Management, Ocean \& Coastal Management, 51:839-846.

[9] Storrier, K.L., McGlashan, D.J., Bonellie, S. and Velandertt, K. (2007): Beach litter deposition at a selection of beaches in the Firth of Forth, Scotland, Journal of Coastal Research, 23(4): 813- 822.

[10] Madzena, A. and Lasiak, T. (1997): Spatial and temporal variations in beach litter on the Transkei coast of south Africa, Marine Pollution Bulletin, 34(11):900-907.

[11] Cervantes, O. and Espejel, I. (2008): Design of an integrated evaluation index for recreational beaches, Ocean \& Coastal Management, 51(5):410419. 